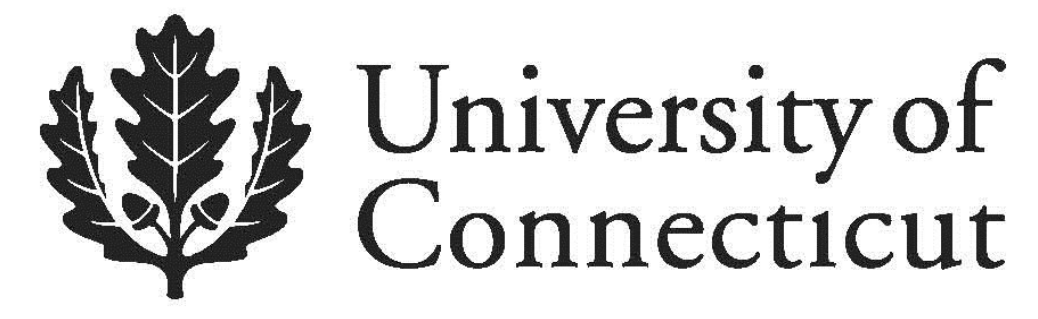

Department of Economics Working Paper Series

\title{
Does Political Reservation for Minorities Affect Child Labor? Evidence from India
}

\author{
Elizabeth Kaletski \\ University of Connecticut
}

Nishith Prakash

University of Connecticut

Working Paper 2014-12

May 2014

365 Fairfield Way, Unit 1063

Storrs, CT 06269-1063

Phone: (860) 486-3022

Fax: (860) 486-4463

http://www.econ.uconn.edu/

This working paper is indexed on RePEc, http://repec.org 


\title{
Does Political Reservation for Minorities Affect Child Labor? Evidence from India
}

\author{
Elizabeth Kaletski ${ }^{1}$ and Nishith Prakash ${ }^{2,3}$
}

This Draft: April 2014

\begin{abstract}
This paper examines the impact of state level political reservation for two minority groupsScheduled Castes and Scheduled Tribes-on child labor in India. We estimate the effect of political reservation on child labor by exploiting the state variation in the share of seats reserved for the two groups in state legislative assemblies mandated by the Constitution of India. Using data from state and household level surveys on fifteen major Indian states, we find that at the household level, Schedule Tribe reservation decreases the incidence of child labor, while Scheduled Caste reservation increases the total number of children working. Our results survive a variety of robustness checks and potential explanations for the differential impact of SC and ST political reservation are also explored, including geographic isolation, caste fragmentation, support for the Congress Party, and decentralization of power.
\end{abstract}

JEL classification: I38, J15, J22, J78.

Keywords: Affirmative action, Minorities, Child labor, India.

\footnotetext{
${ }^{1}$ Kaletski: PhD Candidate, Department Economics, University of Connecticut, Storrs, CT 06269-1063 USA. e-mail: elizabeth.kaletski@uconn.edu.

${ }^{2}$ Prakash: Assistant Professor of Economics, Department of Economics and Human Rights Institute, University of Connecticut, Storrs, CT 06269-1063 USA. e-mail: nishith.prakash@uconn.edu.

${ }^{3}$ We thank Mehtabul Azam, Sonia Bhalotra, Niels-Hugo Blunch, Resul Cesur, Eric Edmonds, Delia Furtado, Nabanita Datta Gupta, Santosh Kumar, Abhiroop Mukhopadhyay, Marc Rockmore, and Zahra Siddique and seminar participants at Department of Economics, University of Connecticut for helpful comments and suggestions. We also thank Pankaj Kumar at Reserve Bank of India who provided us the data on expenditure. We are responsible for any errors that may remain.
} 


\section{Introduction}

Historical discrimination in India has led to the emergence of disadvantaged groups which are excluded from accessing opportunities and resources, resulting in their underrepresentation in politics, public sector jobs, and other areas. In response, the Indian Constitution mandates that a certain share of seats be reserved in the state legislative assemblies and the national parliament (i.e. the Lok Sabha or the lower house) for two minority groups, namely Scheduled Castes (SCs) and Scheduled Tribes (STs). In addition, the federal and state government use policy initiatives to improve the well-being of SCs and STs. Previous studies have estimated the causal impact of political reservation for minorities on a variety of policy outcomes including welfare spending, land reforms, employment, and poverty. However, the majority of these studies look at aggregate outcomes at the state or district level and find mixed results. A related paper by Chin and Prakash (2011) finds that political reservation for STs reduces aggregate poverty in rural India, while political reservation for SCs has no impact. Despite the strong link between poverty and child labor, it remains unclear how these aggregate impacts will translate into household level outcomes. To the best of our knowledge there is no empirical evidence on how these affirmative action policies impact the well-being of minority groups and the overall population. This paper adds to the growing literature on the impacts of affirmative action policies by examining the effect of political reservation on child labor at the household level in India. ${ }^{1}$

Child labor is a particularly relevant measure of well-being because despite efforts to prevent it, the 2001 national census estimates that there are 12.6 million children working in India. Further, child labor rates are known to be especially high for the minority groups of interest in this paper. Thus child labor is likely to be an issue of concern for these groups and one that state elected representatives can directly address. Additionally, because of the

\footnotetext{
${ }^{1}$ It should be noted here that we are assuming a decrease in paid work by children is welfare improving for these households. On the contrary, it could actually be the case that an increase in child labor is a positive outcome in that it could represent a shift from bonded labor to paid work.
} 
complex social relationships in Indian society, minority representation for SCs and STs may actually impact child labor in different ways.

However, estimating the impact of political reservation for minorities on child labor is difficult because political reservation is likely endogenous to the outcome variables of interest. This could occur because the percentage of minorities elected in certain areas or states may vary in ways that also impact the magnitude and intensity of child labor, along with other socioeconomic outcomes. In order to address endogeneity concerns we use the empirical strategy established in Pande (2003) and implemented in Chin and Prakash (2011), which involves isolating the effect of other omitted variables. However, it necessary to point out one important difference from their identification strategy. Pande (2003) and Chin and Prakash (2011) are able to exploit the within-state cross-time variation in the share of seats reserved for minorities because they are using data from 1960-2000. However, we are limited by the availability of only two rounds of nationally representative rural household data from 1982 and 1999. The main advantage of this data is our ability to examine group specific outcomes on child labor at the household level. There are no household surveys that include child labor outcomes dating back to the 1960s. Due to this, we can only exploit the across-state variation in the share of seats reserved. We further elaborate on this strategy in Section 3.

In the case of India, according to the Constitution, the share of seats reserved for the two minority groups is proportional to, and solely determined by, their share of the state population in the last preceding census. One implication of this rule is that minority population share is correlated with minority political reservation, but it may also be correlated with other characteristics that impact child labor. For instance, minority population share could impact how resources are allocated within and across states and therefore how effective policy is in quelling the negative impacts that lead to high child labor prevalence. However, several institutional features allow us to address this issue by directly controlling for both the current and last preceding census minority population share.

The empirical strategy is implemented using state and household level data from multiple 
sources on fifteen major Indian states in 1982 and 1999. Our main findings indicate that at the household level, ST reservation decreases child labor, while SC reservation actually increases the total number of children working. We examine these impacts on the general as well as the disadvantaged group population independently, and also explore potential explanations for the differential impact of SC and ST political reservation. ${ }^{2}$

Political reservation policies for disadvantaged minorities have the potential to affect policy outcomes as a quarter of all legislators in India come from reserved jurisdictions. However, the impact of an increase in minority representation on the well-being of the minority groups and the overall population is an empirical question. It is possible that these policies benefit minorities or non-minorities, by increasing opportunities and available resources. On the other hand, elite capture could occur or any benefits to minority group members could come at the cost of non-minorities. Past empirical literature on the impacts of state level political reservation provides multiple channels through which the shift in resources due to political reservation could impact well-being. For example, Pande (2003) uses data from sixteen major Indian states from 1960-1992, to estimate the impact of SC and ST political reservation on general and targeted government policies separately. ${ }^{3}$ She finds that ST reservation increases spending on ST welfare programs and lowers educational and overall government spending, while SC reservation increases the number of state government jobs reserved for minorities. Despite these results, Pande (2003) concludes that it is still unknown whether the redistribution in spending and job quotas enhances the well-being of the minority groups or the general population. This is particularly important for our present study as increased welfare spending could result in improved circumstances at the household level leading to a potential decline in child labor. On the other hand, if the increased spending results in a higher rate of economic activity or trade, an increase in demand could cause child labor prevalence to rise.

\footnotetext{
${ }^{2}$ Here disadvantaged groups are defined as Scheduled Castes, Scheduled Tribes, and Other Backward Class.

${ }^{3}$ In Pande (2003) general government policies include total per capita state spending, total education spending, and whether or not a land reform act occurs. Targeted policies include the fraction of government spending going towards SC and ST welfare programs, along with job quotas for those groups.
} 
Similarly, if elite capture occurs or a decrease in education spending results in the lowering of the availability or quality of education, households may actually find themselves in worse situations where child labor is more necessary.

In a related paper by Krishnan (2007) the importance of access to education is further exhibited. Krishnan (2007) finds that SC legislators improve access to primary schools, which benefit both SC and non-SC groups, while ST legislators perform similarly to legislators in unreserved constituencies. ${ }^{4}$ These results confirm the idea that SC and ST reservation may impact child labor in different ways and provide an additional channel through which that may occur.

Further, in order to address well-being at the aggregate level, Chin and Prakash (2011) look at the impacts of minority representation on poverty outcomes, finding that increasing the share of minority seats reserved for STs reduces overall poverty, while SC reservation has no impact on poverty. The child labor literature has established a strong link between poverty and child labor. In particular, decreases in poverty (or increases in income) is one of the most important mechanisms to improving child labor outcomes. However, this relationship is by no means a requirement. It is also possible that any decrease in poverty could actually be a direct result of children entering the labor market in order to help reach subsistence consumption. To clarify, the results in Chin and Prakash are for overall poverty rates in the general population. Households that tend to send children to work are extremely poor and are not necessarily the same households which see improvements in poverty with ST reservation. Improvements in poverty rates are more likely to occur near the poverty line than in households far below it. Thus it remains unclear how these aggregate impacts will

\footnotetext{
${ }^{4}$ Krishnan (2007) is examining whether districts represented by more minority legislators provide different public goods relative to non-minority representatives. In this case public goods refer to availability of educational and health facilities. She concludes that there is no evidence to support the theory that political reservation negatively impacts electoral competition or the quality of legislators.
} 
translate into household level outcomes. ${ }^{5}$

Previous literature has focused on how state level political reservation impacts aggregate policy outcomes and provides several potential links between reservation and well-being. We are not aware of any paper that examines the effect of political reservation for minorities on micro-level well-being outcomes, nor more specifically on child labor. This paper adds to the existing literature on mandated affirmative action policies by exploring the impacts of political reservation on child labor at the household level. Moreover, we examine group specific and general population child labor outcomes separately, while also allowing for differential impacts across gender.

The remainder of this paper proceeds as follows: Section 2 discusses the background on political reservation policies and the prevalence of child labor among minorities. Section 3 presents the empirical framework and Section 4 describes the data. Section 5 reports the main empirical results, while Section 6 discusses some robustness checks. Section 7 then describes the results on the heterogeneous effects of political reservation for minorities. Section 8 concludes.

\footnotetext{
${ }^{5}$ Several studies have also explored the impact of women's and local level SC and ST reservation. For example, Chattopadhyay and Duflo (2004) find that women representatives in the Gram Panchayat (bottom tier of local government) tend to shift spending towards the allocation of local public goods, such as drinking water and roads. On the other hand, Bardhan et al. (2010) find no significant effects of women pradhan (mayor) reservations on the same public policy aspects in West Bengal. Mookherjee (2012) provides a summary of these, along with similar papers, and concludes that it is still unclear if women reservations will have long run impacts on policies. In the case of SC and ST reservation at the village level, SC and ST pradhans increase the probability that households in that village have a toilet, electricity connection, and private waterline (Besley, Pande, Rahman and Rao, 2004), as well as increase the benefits from the local government for housing construction and improvements (Bardhan, Mookherjee and Parra Torrado, 2010). Similarly, having an SC pradhan increases public goods to areas where SCs are concentrated (Duflo, Fischer and Chattopadhyay, 2008).
} 


\section{Background}

\subsection{Political Reservation in State Legislative Assemblies in India}

This paper focuses on two specific minority groups, SCs and STs, who make up $16.6 \%$ and $8.6 \%$ of the population respectively. ${ }^{6}$ SCs are those groups with low social and ritual standing in the Hindu caste hierarchy, while STs are groups identified by their tribal culture, geographic isolation, and linguistic characteristics. ${ }^{7,8}$ Both of these groups have been historically discriminated against and prevented from engaging in opportunities or claiming rights that could improve their status in Indian society. Much of this stems from discrimination in the Hindu caste system which determined that SC members took menial jobs and were restricted from owning assets. Similarly, geographic isolation and reliance on subsistence agricultural led to widespread poverty among STs (Pande, 2003).

In order to correct this historical discrimination, India has a long history of aggressive and mandated affirmative action policies aimed at increasing opportunities for disadvantaged groups in education, public sector employment and political reservation. The Constitution, effective January 26, 1950, requires representation for SCs and STs in the lower house of Parliament (Lok Sabha) and state legislative assemblies. ${ }^{9}$ More specifically, Article 332 of the Indian Constitution establishes that the number of seats reserved for SCs and STs in the state legislative assemblies is determined by the share of that group's total state population in the last preceding census. Thus the primary source of variation is the arrival of the new census population data. ${ }^{10}$

\footnotetext{
${ }^{6}$ These estimates are based on the 2011 Census data.

${ }^{7}$ These groups were formally referred to as untouchables or backward castes.

${ }^{8}$ The Indian Constitution, specifically the Schedule Castes and Scheduled Tribe Order of 1950, stipulates which groups are considered SCs and STs. Further, the SC and ST Orders Act of 1976 requires that SC and ST definitions be uniform across all states.

${ }^{9}$ Further, decentralization of the government of India and representation of SCs and STs at the local government level was established in 1993 by the 73rd and 74th amendments. Specifically, the 73rd amendment addressed local governments in rural areas, while the 74th targets urban areas.

${ }^{10}$ It should be noted that only members of the given group can be elected to the reserved seats, but they are elected by all voters in the territory regardless of voters' social background.
} 
Upon the arrival of new census figures, the Delimitation Commission is then responsible for revising the number of seats reserved in each state for SCs and STs, along with designating the specific constituencies in which they are reserved. ${ }^{11}$ Additional variation arises across states due to the time lag until the Delimitation Commission revises reservations based on new population counts and the fact that changes are not actually applied until the next election, which varies randomly across states. The data used here cover 1982 and 1999, but since the 42nd amendment in 1976 suspended new delimitations until after 2000, all reserved seats are based on the 1971 census. This factor then limits us to exploiting the across-state variation using the two rounds of household data.

Any additional variation in the share of seats reserved is based on institutional changes imposed by the national government. This could include a change in the number of constituencies or the definitions of SC and ST. ${ }^{12}$ Thus both the source of any change in seats reserved, along with the time lags in which they actually take effect, are used to identify the impact of political reservation on child labor. ${ }^{13}$

The elected state legislatures are largely autonomous from the central government and their responsibilities are laid out in the Indian Constitution. These responsibilities include ensuring public order, along with overseeing public health and sanitation, intrastate roads, water, land, agriculture and industry. Additionally, education, social security and insurance, and labor are jointly determined by the central and state governments. The main channel for the state government to affect outcomes is through allocation of state level spending, establishing and enforcing laws, outlining priorities, and supervising lower government levels (Chin and Prakash, 2011). This structure leaves multiple channels through which reservation of minority groups can impact policy as well as child labor outcomes.

\footnotetext{
${ }^{11}$ The Indian Constitution states that seats for STs are to be reserved in the constituencies where their population share is highest. On the other hand, SCs should be distributed in different parts of state, primarily where their population share is relatively high (Krishnan, 2007).

${ }^{12}$ This occurred in 1961 when two seat constituencies were abolished, but is outside the range of our dataset.

${ }^{13}$ Chin and Prakash (2011) provide a list the sources of variation in the share of seats reserved in Table 1 of their paper.
} 


\subsection{Prevalence of Child Labor among Schedule Castes, Scheduled Tribes and Other Backward Classes in India}

It is well recognized by the Indian government that child labor remains a significant problem in the country and is highly related to poverty and illiteracy. The first committee on child labor was established in 1979, and by 1986 the Child Labour (Prohibition \& Regulation) Act was passed, which banned child labor in hazardous occupations and sought to regulate it in other areas (Government of India, Ministry of Labour \& Employment, 2013). ${ }^{14,15}$ Despite this effort, the 2001 census estimates that 12.6 million children are working in the country, often 14 hours a day in industries banned under the Act of 1986. These numbers are highest in rural areas and within ST and SC groups, as well as among the Other Backward Classes (OBCs) (Childline India Foundation, 2013). For example, child labor rates are 11.6\% among SCs and 16.6\% among STs (UNICEF, 2011). ${ }^{16}$ The high prevalence of child workers in $\mathrm{SC}, \mathrm{ST}$ and OBC populations is partly related to a culture of bonded labor in which parents often pledge their children in return for loans (Babu, 2006). Thus child labor is an important measure of well-being and likely to be an issue of concern for these minority groups. Further, as previously discussed, state elected representatives have the ability to directly and indirectly address this issue through policy. ${ }^{17}$

\section{$3 \quad$ Empirical Strategy}

As discussed in Section 1, minority political reservation can either increase or decrease the amount of child labor. It may be the case that minorities and the general population

\footnotetext{
${ }^{14}$ The National Policy on Child Labor was established in 1987 (along with the National Child Labor Project of 1988) which sought to rehabilitate working children by providing education, food and training.

${ }^{15}$ In 2013, India revised it's stance on child labor by introducing a bill that would abolish all forms of child labor (and specifically work by children under the age of 14). This is in line with ILO Convention 138 on the minimum age of employment and India's Right to Free and Compulsory Education Act which states that all children between age 6 and 14 must be in school.

${ }^{16}$ This is relative to child labor rate of $9.7 \%$ among other groups.

${ }^{17}$ For example, child labor could be impacted by the shift in resources that occurs with minority reservation as in Pande (2003) and Kishnan (2007).
} 
benefit if SC and ST political reservation leads to a change in the allocation of resources which decreases child labor. This could occur if more poor minorities are receiving welfare services and therefore find it less essential to send children to work in order to meet subsistence consumption. However, it is also possible that SC and ST reservation leads to inefficient resource allocation or a shift away from policies that would benefit poor households. This could also lead to a situation or exacerbate circumstances under which households are forced to send more children to work in order to compensate for any lost government services. Thus, it is an empirical question whether minority political reservation impacts the incidence of child labor.

Following the empirical strategy established in Pande (2003) and implemented in Chin and Prakash (2011), the relationship between minority share of legislative seats and child labor can be estimated as:

$$
y_{i s t}=\alpha_{t}+\sigma_{r}+\beta_{1} S C \operatorname{Res}_{s}+\beta_{2} S T \operatorname{Res}_{s}+e_{i s t}
$$

where $y_{i s t}$ is the total number of children working in household i in state s at time t. SC Reps and ST Rep are the share of seats reserved for the SCs and STs in state legislative assemblies, respectively. It should be noted here that because there are almost no seats won by SCs or STs in unreserved constituencies, there is no distinction between the share of seats held by SCs and STs and the share of seats reserved. $\alpha_{t}$ and $\sigma_{r}$ are time and region fixed effects, which control for any time-invariant region characteristics and macroeconomic shocks or national policies that affect all states uniformly. ${ }^{18}$ The coefficients of interest here are $\beta_{1}$ and $\beta_{2}$, which estimate the effect of SC and ST political representation on the total number of children working in a given household.

Estimating Equation (1) will not give the causal effect of SC and ST political reservation on child labor. The first likely concern is the presence of omitted variable bias. States that

\footnotetext{
${ }^{18}$ States are classified as belonging to five distinct regions: North, Northeast, South, West and East.
} 
elect a greater number of SC and ST state legislators are likely to be different in other ways that also affect child labor. For example, individuals in those areas may discriminate less, which could impact certain social groups and household opportunities. However, given the Constitutional Order of 1950, state governments have no discretion regarding the implementation of this policy. In fact, all states must follow the same policy rule in determining minority representation. Therefore any changes in SC and ST political reservation is exogenous to the state as they only occur based on new census counts or institutional changes from the central government.

An additional concern arises based on this policy rule. Specifically, the rule indicates that the share of seats reserved is proportional to the minority population share in the last preceding census, implying that minority population share is correlated with minority political reservation. It could also be the case that minority population share is related to how resources are allocated within and across states and therefore how effective the policy is in quelling the negative impacts that lead to high child labor prevalence. One solution to this problem is to directly control for minority population share in Equation (1).

However, if minority population share always equals the share of seats reserved, perfect collinearity would prevent us from estimating the impact of minority reserved seats on child labor. In order to address this issue we exploit the specific characteristics of the policy rule and its implementation process. First, we know that the policy rule is based on the last preceding census, so it is still possible to control for minority population share in state s at time t. In addition, our data is drawn from a sample after 1976 when the 42nd Amendment suspended new delimitation until 2000. Therefore the political reservations are based on the 1971 census. These factors allow us to control for both the current minority population share in 1982 and 1999 along with the minority population shares in the last preceding decennial census of 1981 and 1991. Table 1 displays how current and census population, along with the actual reservation share differ by state within the sample. Thus we can separate the effect of minority census population share from minority political reservation and identify the impact 
on child labor off the variation in share of seats reserved across states for the two minority groups.

We modify Equation (1) above to estimate the following:

$$
\begin{array}{r}
y_{i s t}=\alpha_{t}+\sigma_{r}+\beta_{1} S C \text { Res }_{s}+\beta_{2} S T \text { Res }_{s}+\gamma_{1} \text { Current Pop } \text { Put } \\
+\gamma_{2} \text { Census } \text { Pop }_{s t}+\delta X_{s t}+\rho Z_{i t}+e_{i s t}
\end{array}
$$

here Current Pop st is the minority share of the population in state s at time t and Census Popst is the minority share of the population in the last preceding census in state s at time t. In some specifications we further control for additional state and household level characteristics, $X_{s t}$ and $Z_{i t}$. The variables in $X_{s t}$ are state level controls including per capita state income last year, a dummy for election year, and rural share of the population, along with expenditure controls including the log of total state expenditure per capita, the education expenditure share, and the disadvantaged group welfare expenditure share. The variables in $Z_{i t}$ include caste dummies for SC, ST, Other High Caste, Brahmin, and Other Backward Class, religion dummies for Hindu and Muslim, log of household expenditures, household size, the household head's education and a dummy for the household head's activity status. ${ }^{19}$

\section{Data}

We use data from a variety of sources to implement our empirical strategy. The primary source is two rounds of ARIS/REDS data from 1982 and 1999. ARIS/REDS is a large, nationally representative sample of rural households from fifteen major states in India. ${ }^{20}$ Our key outcome variable, child labor, along with household level and demographic controls, come

\footnotetext{
${ }^{19}$ The omitted category is Other High Caste. All expenditures variables have been adjusted using the Indian consumer price index (CPI) and are in 1999 Indian Rupees (INR).

${ }^{20}$ The states included are Andhra Pradesh, Assam, Bihar, Gujarat, Haryana, Karnataka, Kerala, Madhya Pradesh, Maharashtra, Orissa, Punjab, Rajasthan, Tamil Nadu, Uttar Pradesh and West Bengal. As noted in Table 1, we only have data for Assam in 1999.
} 
exclusively from the 1982 and 1999 rounds of the ARIS/REDS dataset. ${ }^{21}$ The household level data on child labor include 8,042 household-year observations in rural areas across these fifteen states.

The child labor variable measures the total number of children working between the ages of 5 and 14 in a given household. This variable includes paid working activities which could occur either outside or within the household. These activities include self-employment in either farming or non-farming, salary work, agricultural and non-agricultural wage work, and agricultural or non-agricultural family work. Specific tasks within these broad categories include, but are not necessarily limited to, preparatory tillage, sowing, weeding, irrigation, harvesting, land improvement, construction, tending livestock and milk production.

Our main independent variables of interest and some of the additional controls are borrowed from Chin and Prakash (2011). These include the minority political reservation variables, measured as the percentage of seats in state assembly reserved for SCs and the percentage of seats in state assembly reserved for STs. These data, along with the dummy for election year which equals one when there is a state election in year $t$, were originally drawn from the Election Commission of India reports on state elections. The minority population share variables based on the current and last preceding census estimates, were originally drawn from the Census of India, Registrar General. The state income per capita data is from the Planning Commission, Government of India. The rural population share is drawn from Ozler et al. (1996) and was originally computed from the National Sample Survey. The expenditure controls for 1982 are taken from Pande (2003) and come originally from the Reserve Bank of India Report on Currency and Finance and the Ministry of Welfare Handbook. For 1999, expenditure controls are taken solely from the Reserve Bank of India State Finances publication. ${ }^{22}$ Table 2 reports the descriptive statistics for the variables used

\footnotetext{
${ }^{21}$ These include SC, ST, Other High Caste, Brahim, and OBC dummies, Hindu and Muslim dummies, household expenditures, family size, household head's education and household head's employment status.

${ }^{22}$ These data are calculated in the same way despite coming from different sources. The social security and welfare spending data are from the RBI for both 1982 and 1999.
} 
in our estimation.

\section{$5 \quad$ Main Results}

\subsection{Effects of Political Reservation on Child Labor}

Our first set of results estimates the overall effect of minority reservation on the total number of children working in a given household. ${ }^{23}$ The results from Equation (2) are presented in Table 3. In Column 1, we only control for demographic characteristics, including caste and religion dummies. Column 2 includes additional household level controls (e.g. household expenditures, family size, household head education and household head employment), while Column 3 further adds other state level controls (e.g. state income last year, election year dummy, and rural population share). Our preferred specification is presented in Column 4 of Table 3 and also controls for total state expenditure, education expenditure share, and social security and welfare expenditure share. It should be noted here that these expenditures controls are endogenous as they are the outcomes of interest in Pande's (2003) analysis. However, since child labor prevalence is likely impacted by education and welfare spending in particular, they are included as additional controls. Their inclusion does not seem to impact the overall results. All results presented include region and year fixed effects with standard errors clustered at the state level. ${ }^{24}$

Columns 1 through 4 indicate that regardless of the additional controls included, the percentage of seats reserved for ST members (ST share reserved) leads to a decrease in the total number of children working. In contrast, the percentage of seats reserved for SC members (SC share reserved) increases the total number of children working, though the results are not statistically significant at the conventional level across all specifications. More specifically, Column 4 shows that a one percentage point increase in the share of seats

\footnotetext{
${ }^{23}$ These estimates include all households in the sample regardless of their classification into minority groups.

${ }^{24}$ All results are also run using robust standard errors. Clustering at the state level results in larger standard errors and thus they are presented in the main results as they are more conservative.
} 
reserved in the state legislative assembly for STs leads to a .097 decrease in the number of children working in a given household, while SC reservation leads to a .014 increase, though the results are not significant in the full specification. ${ }^{25}$

The difference in outcomes across the two minority groups is striking. The decrease in child labor that results from ST reservation is consistent with the results found in Pande (2003), which indicate that ST reservation leads to an increase in welfare spending. Further, Chin and Prakash (2011) also find that ST reservation leads to a decrease in overall poverty. Given the strong documented link between poverty and child labor, it is not surprising that child labor declines with increased ST reservation. Child labor is a short run mechanism which households use in order to reach subsistence consumption. Households have an alternative to using child labor as welfare benefits increase, and they additionally find child labor less necessary as poverty declines.

In addition, more insight can be derived from comparing the main results to the results on the sample of only disadvantaged households in Table $4 .^{26}$ These results indicate that the decrease in child labor that results from ST reservation holds for both the full sample as well as the disadvantaged group population. Further, although still not significant in the full specification, the increase in child labor that results from SC reservation is larger in magnitude for the sample of disadvantaged households. The increase in well-being that results from ST reservation could also be due to the fact that STs tend to be more geographically isolated (Pande, 2003). This would allow representatives to enact policies that directly benefit their own social group and to address the major concerns within that group. Given that child labor is especially high within ST groups, it is likely an issue of concern among the constituents ST representatives cater to. Due to these factors, it is not surprising that ST reservation decreases the incidence of child labor. These results are also consistent with

\footnotetext{
${ }^{25} \mathrm{On}$ average there are 2.34 children between the age of 5 and 14 in these households. Based on the summary statistics of Table 2, 0.36 of them are currently engaged in work which translates into about $15.38 \%$. A decrease of .097 children working in the average household is a decline of about 4.14 percentage points.

${ }^{26}$ In this case, disadvantaged households include SC, ST and OBC households.
} 
other research in the area, which finds differential impacts across SC and ST reservation (Chin and Prakash, 2011; Pande, 2003; Krishnan, 2007).

In order to test the difference across these groups more formally, we run the same specifications for ST and SC households separately. The results are found in Tables 10 and 11 of Appendix A1. This severely cuts down on our total number of observations, but the results across the two different groups are particularly apparent. In Table 10, using only SC households, we find that the coefficient on ST reservation is similar in magnitude and significance relative to the results in Tables 3 and 4 . However, the increase in child labor that results from SC reservation is now statistically significant throughout. In contrast, Table 11 shows that within ST households, neither ST or SC reservation has any significant impact on child labor. At least within disadvantaged households, the results seem to be driven by a change in SC households. Due to their isolation and culture, ST households may be less susceptible to change in response to minority reservations, while SC households are more integrated with the rest of society and therefore more influenced by this policy.

The increase in child labor that results from SC reservation is surprising. In line with the argument above, the geographic dispersion of SC representatives may cause them to enact policies that appease a broader range of constituents rather than directly targeting issues which are of concern for their specific social group (Krishnan, 2007). If child labor is not a major issue of contention within the broader population, SC representatives are less likely to make that a policy priority. Another explanation for this result stems out of Pande's (2003) findings that SC reservation tends to lead to increased job opportunities for SC members. One possible interpretation of this result is elite capture among the SCs, where only the best off individuals actually benefit from the policy. Further, any benefits may come at the expense of other non-minorities. If this is the case, there is no reason to expect improved well-being outcomes in either the general population or within disadvantaged households.

It is further possible that $\mathrm{SC}$ reservation results in a shift in resources that increases economic activity and trade. This could then result in increased labor demand, which has 
the ability to impact both adult and child labor. Edmonds et al. (2010) show that child time allocation is influenced by changes in children's economic opportunities. More specifically, in examining India's 1991 tariff reform, they find smaller improvements in schooling and declines in child labor within cities where tariff reduction was largest. Although we do not have specific details on the impact of political reservation on wages, occupations or opportunities, an increase in labor demand may result in an increase in wages for children, causing more children to enter the labor market as the returns to work increase. It should also be noted that we are assuming a decrease in paid work by children is welfare improving for these households. On the contrary, it could actually be the case that an increase in child labor is a positive outcome in that it could represent a shift within SC households from bonded labor to paid work. This implies an increase in total household income and potentially an increase in consumption. In this case, we do not have any information on bonded labor so the welfare implications are difficult to tease out. However, given that the results appear to be slightly less robust in the full sample, we cannot read too much into them.

One concern that arises when using a repeated cross-section of data from 1982 and 1999 is that despite the fact that the share of seats reserved for minorities is not changing over time, the actual representatives are. Given that the identity of the leader is changing, this could result in a difference in outcomes based on differences across preferences or the effectiveness of leadership. In order to address this concern, we also run the regressions for 1982 and 1999 separately. The results indicate that this does not seem to be a concern as the individual year estimates are consistent with the results presented above. These tables are omitted for brevity, but are available upon request. Although it would be nice to pin down the exact mechanisms behind our results, our current data does not allow us to do so. We leave this as an additional task for future research. 


\subsection{Effects of Political Reservation on Child Labor by Gender}

In order to get a clearer picture of these impacts, Table 5 presents the results using total working boys in Columns 1-4 and total working girls in Columns 5-8 as the dependent variable. Although the results of Table 5 are qualitatively similar to Table 3 , the magnitudes of the coefficients are smaller in all cases. Specifically, Column 4 shows that for the total number of boys working, the coefficient on SC share reserved is -.006 (again not statistically significant), while the coefficient on ST share reservation is -.049. The decreased magnitude of the coefficient is due to the fact that boys only make up a fraction of the total working population.

On the other hand, for the total number of girls working, Column 8 indicates that the coefficient on SC reservation is .019, while the coefficient on ST reservation is -.049. The impacts of SC reservation appear more robust in the case of female child labor. ${ }^{27}$ Thus it appears that the negative impacts from SC reservation, which result in a increase in child labor, are more likely to occur in the female population than in the male. Statistically, the coefficients on SC reservation are different across genders, while the coefficients on ST reservation are not. ${ }^{28}$ Table 6 presents the same results by gender using that sample of only disadvantaged households. The results indicate that the decrease in child labor that occurs with ST reservation holds across the general population and within disadvantaged groups, regardless of gender. However, the gender bias, which results in an increase in child labor with SC reservation, is particularly pronounced when looking at the sample of disadvantaged groups only.

These results are slightly surprising given the fact that males in this sample are on average more likely to be working than their female counterparts. However, this could reflect the idea that girls are more likely to withdraw from school than boys, indicating a gender bias towards

\footnotetext{
${ }^{27}$ The coefficient in Column 8 of Table 5 is marginally statistically significant at the $13 \%$ level.

${ }^{28}$ Statistical tests of a null hypothesis that the coefficient on SC reservation for girls is equal to the coefficient on SC reservation for boys are rejected with a Chi-Squared value of 15.98. On the other hand, we fail to reject the null hypothesis that the coefficient on ST reservation for girls is equal to the coefficient on ST reservation for boys with a Chi-Squared value of 0.00 .
} 
male children. Again, this result is consistent with evidence in Edmonds et al. (2010) which shows that girls bear a particularly large portion of the burden of household poverty.

Although the results are somewhat surprising, they are consistent with what the literature has found up to this point. However, we caution the readers that there is no direct theory and we only present the reduced form results. Thus the exact mechanisms behind the results cannot be teased out. We further explore other potential heterogeneities behind the difference in outcomes across ST and SC reservation in Section 7 below.

\section{Robustness Checks}

Up to this point we have assumed that the estimated coefficients of the SC and ST minority reservation shares represent causal estimates of the impact of minority political reservation on child labor outcomes. In the following sub-sections we explore the robustness of these results by examining factors that may confound them. More specifically, we examine the impact of controlling for additional household composition, augmenting our child labor variable, and including state random effects. The results from these robustness checks are shown in Columns 2 though 4 of Table 7 . For the purpose of comparison, the original results of the full specification for total children, boys working and girls working are shown in Panels $\mathrm{A}, \mathrm{B}$ and $\mathrm{C}$ of Column 1 respectively.

\subsection{Household Composition}

As our dependent variable is the total number of children working, we control for family size in our original specification. However, this may not be enough as all children's ages and genders are likely to play an essential role in whether or not certain children work in a given household. For instance, older girls may need to work in order to finance additional expenditure for their younger male siblings. In order to account for this, in Column 2 of Table 7 we independently control for the number of girls and boys age 0-4, 5-9, and 10-14 in 
the household. Overall, the results are qualitatively similar to the main specification shown in Column 1.

\subsection{Selection of Child Labor Variable}

In addition, it is possible that the results are driven by the selection of our child labor variable. Instead of relying solely on the total number of children working in a household, we replace our dependent variable with a binary one which is equal to one if the household has at least one child between the age of 5-14 working, zero otherwise. This type of exercise more directly targets the decision to send any child to work rather than the decision to send an additional child to work. If a household already has children working, child labor is likely more acceptable than in a household where no children are currently employed. In Panel A of Column 3, the dependent variable is equal to one if there is a child of any gender working, while in Panels $\mathrm{B}$ and $\mathrm{C}$ it equals one if there is a boy or girl working, respectively. The results on ST reservation are robust to selection of the child labor variable.

\subsection{State Random Effects}

The results up to this point have been presented with standard errors clustered at the state level. In doing so, we have relaxed the assumption of independence across states. More specifically, we allow for arbitrary correlation within states, and allow the form of this correlation to vary from state to state. If instead we run the same regression using state level random effects, we will have the same coefficient estimates, but we remove any differences across states, resulting in a reduced error term. This of course requires us to make assumptions about the correlation of households within states, but we improve the precision of our estimates. The results including state random effects are shown in Column 4 of Table 7. 


\section{Exploring the Heterogeneous Impacts}

There are a number of factors that may provide insight into the differential impact across $\mathrm{SC}$ and ST political reservation on child labor. In particular, in this section we explore the differences across the two groups in terms of geographic isolation, caste fragmentation, support for the Congress Party, and a shift in power from the central to local government. Table 8 shows the heterogeneous impacts on child labor using the full sample of households, while Table 9 displays the results broken down by gender. The baseline results using the full specification from Tables 3 and 5 are shown in Column 1 of Tables 8 and 9 for comparison.

\subsection{Geographic Isolation}

As mentioned, STs tend to be more geographically isolated and are concentrated in specific areas, while SCs are more geographically dispersed. This difference may then have differential impacts on child labor outcomes. For one, SC representatives may need to cater to a broader base of constituents, while ST representatives may have the ability to directly target policies towards ST members. Thus the preferences of these two groups, along with the preferences of the specific representatives, may differ substantially. ST representatives may be more inclined to make decreasing child labor a policy goal because it is a prevalent problem within their social group. On the other hand, in catering to a broader base of constituents, decreasing the amount of child labor may not be a priority for SC representatives and therefore policy makers may ignore or even exasperate the issue.

In order to explore this idea we allow the impacts of minority reservation to vary by an index of geographic isolation. Following Chin and Prakash (2011), we use an index of isolation which measures the probability that the average minority in an Indian state will meet another minority adjusted by the prevalence of minorities in the state. In line with the discussion above, the adjusted means of these variables for SCs (.02) and STs (.13) indicate 
that STs are more much geographically isolated. ${ }^{29}$

In Column 2 of Table 8, the full specification of Equation (2) is estimated adding the interaction between minority reservation and the geographic isolation variable. In comparing the coefficients in Column 2 to those in Column 1, the results indicate that the inclusion of these interaction terms does not change the overall impact of ST reservation on child labor. The coefficient on ST reservation is similar to the original results, but the interaction of ST reservation and geographic isolation is also positive and statistically significant. Therefore geographic isolation may play a role in that as STs become more isolated, the impact of ST reservation on child labor is diminished. Given that the results in Appendix A1 indicate that ST households are rarely the ones benefiting from ST reservation, it is consistent to argue that greater geographic dispersion implies better overall outcomes in terms of child labor.

On the other hand, the impact on $\mathrm{SC}$ reservation is in sharp contrast to what the results have shown up to this point. In fact, both the coefficient on SC reservation and the interaction term are negative and statistically significant. This may indicate the fact that in a group that is already geographically dispersed, increasing isolation could result in better targeting of policies.

\subsection{Caste Fragmentation}

Caste fragmentation tends to be greater within SCs as there are numerous sub-castes within the group and there is greater heterogeneity across SC members, relative to ST members. On the other hand, STs tend to be more homogeneous and have fewer sub-castes within the group, particularly in the local communities in which they live. In line with the discussion regarding geographic isolation, this could imply that SC representatives need to cater to a broader base of preferences. On the other hand, homogeneity among STs could lead to a greater focus on child labor making it a priority for state representatives.

We test the idea that caste fragmentation and social heterogeneity could play an im-

\footnotetext{
${ }^{29}$ See Chin and Prakash (2011) for more details on the calculation of this index.
} 
portant role in the differences across the two groups in Column 3 of Table 8 . We add an interaction between minority group reservation and district caste fragmentation weighted by state level population. ${ }^{30}$ The results indicate that increased caste fragmentation does not change the effect of political reservation for STs, but may improve outcomes for SC reservation. However, the overall impact of SC reservation remains insignificant.

\subsection{Support for the Congress Party}

Although the Congress Party, which is known for its' anti-poverty stance, has historically dominated Indian politics, there has been a shift of support in recent years. More specifically, although STs have tended to persistently support the party, SCs have decreased support over the years. It is possible that this shift in support has resulted in differential impacts among SCs and STs. Following Chin and Prakash (2011), we asses this impact using an interaction between minority group reservation and a dummy variable equal to one if the share of reserved seats won by Congress in the lower Parliament is at least $50 \%$.

The results shown in Column 4 of Table 8 indicate that support for the Congress party does seem to play an important role. Both the coefficient on ST reservation and the interaction of Congress support with ST reservation are negative and statistically significant. This is not surprising given the increase in Congress Party support among STs and their anti-poverty stance. Given the strong link between poverty and child labor, increased focus on poverty is likely to result in decreased child labor.

\subsection{Reservation After the 73rd and 74th Amendments}

The 73rd and 74th Amendments to the Indian Constitution, which came into effect in April 1993 were designed to give more power to the local level of government. As mentioned

\footnotetext{
${ }^{30}$ The district caste fragmentation measure comes from from Banerjee and Somanathan (2007). According to Banerjee and Somanathan. India has a great deal of social heterogeneity; on average in the 16 states, the index is 0.93, compared to 0.29 calculated by Alesina et al. (1999) for US cities using racial groups.
} 
earlier, these amendments mandated one-third representation at the local level for women and minority group members. Although the federal and state governments in India continue to be highly centralized, the 73rd and 74th amendments gave local authorities the ability to allocate funds for infrastructure and select beneficiaries for welfare programs (Chin and Prakash, 2011). The impact of this shift in power could work in several ways. It could be the case that having local representatives with power is more conducive to policies which directly target the major issues in that particular community. If child labor is a pervasive problem, then policies could directly work to improve the situation. On the other hand, if child labor is acceptable in a given community since most children already work, it will not be of an issue of utmost concern and policies implemented by local authorities may actually exasperate the problem.

In order to test this hypothesis we allow the effect of reservation to vary before and after 1993 when the amendments were passed. Column 5 of Table 8 adds an interaction between political reservation and a dummy for 1993 or after. The results indicate that ST reservation still has a negative and statistically significant coefficient, but the magnitude of the impact has decreased. Further, both coefficients on the interaction terms are positive and statistically significant. Thus the shift in power from the state to local governing bodies, may have actually made the issue of child labor worse. One explanation for this result is that the central government has made decreasing child labor a policy priority. However, it is unclear that local governments have similar priorities. Thus when power shifts towards more local levels child labor loses focus, leading to an increase in its incidence. Further, there may be some kind of conflict of interest between state and local governing bodies that exasperates already existing issues.

The results of these heterogeneous impacts are also shown using male and female children working as the dependent variables in Panel A and B of Table 9. The results support those presented above. In particular, geographic isolation, caste fragmentation, support for the Congress Party, and the passing of the 73rd and 74th amendments appear to impact the 
amount of child labor in various ways. ${ }^{31}$

\section{Discussion}

To the best of our knowledge this is the first paper to explore the impact of political reservation for SC and ST members on well-being outcomes of households in Indian states. Using nationally representative household and state level data and exploiting the structure of the legislature and the timing of elections, we show that political reservation for minorities significantly impacts child labor. Specifically, we find that ST reservation decreases the total number of children working within a household, while SC reservation increases the total number of children working, though the results for SCs are not robust. A one percentage point increase in seats reserved for STs in the state legislative assembly leads to .097 decrease in the total number of children working in a given household. On the other hand, a one percentage point increase in seats reserved for SCs leads to a .014 increase in the total number of children working (though not statistically significant).

Under the assumption that a decrease in paid work is positive for well-being, there is also some evidence of a gender bias in the impact, which can potentially lead to worse outcomes for female children. The results are consistent with research which finds differential impacts across SC and ST reservation. Several reasons behind the heterogeneous impacts are also explored. In particular, geographic isolation, caste fragmentation, support for the Congress Party, and decentralization of power all impact the amount of child labor. As discussed, the decrease in child labor, which occurs as the share of seats reserved for STs increases, could be a reflection of the improvements in poverty outcomes, the preferences of STs, or the increase in welfare program spending (Chin and Prakash, 2011; Pande, 2003).

The difference in impacts across minority groups provides support for the idea that the consequences of affirmative action policies cannot be generalized to other situations. There

\footnotetext{
${ }^{31}$ These results were also run for disadvantaged households, but are omitted for brevity.
} 
are many potential impacts of affirmative action policies and this paper provides evidence that the actual impact depends on the exact policy and the population in which it is explored. Additionally, it provides evidence that affirmative action policies may have unintended consequences on both the general population and minority group members. This paper is the first to look at the impacts of political reservation on child labor outcomes in India. Future research should seek to further understand the mechanisms behind any differences in outcomes across the gender of children and the heterogeneity in the impacts of the minority groups. 


\section{References}

Alesina, Alberto; Baqir, Reza and Easterly, William. "Public Goods and Ethnic Divisions." Quarterly Journal of Economics, 1999, 114 (4), pp.1243-1284.

Banerjee, Abhijit and Somanathan, Rohini. "The Political Economy of Public Goods: Some Evidence from India." Journal of Development Economics, 2007, pp. 287-314.

Babu, Suresh. "Child Labour in India: Problems and Conceptualisation." Think India Quarterly, 2006, 9 (3).

Bardhan, Pranab; Mookherjee, Dilip and Parra Torrado, Monica L. "Impact of Political Reservations in West Bengal Local Governments on Anti-Poverty Targeting." Journal of Globalization and Development, 2010, 1 (1), Article 5.

Bertrand, Marianne; Hanna, Rema and Sendhil Mullainathan. "Affirmative Action in Education: Evidence From Engineering College Admissions in India." Journal of Public Economics, February 2010, 94 (1-2), pp. 16-29.

Besley, Timothy; Pande, Rohini; Rahman, Lupin and Rao, Vijayendra. "The Politics of Public Good Provision: Evidence from Indian Local Governments." Journal of the European Economic Association Papers and Proceedings, April-May 2004, 2 (2-3), pp. 416-426.

Chattopadhyay, Raghabendra and Duflo, Esther. "Women as Policy Makers: Evidence from a Randomized Policy Experiment in India." Econometrica, September 2004, 72 (5), pp. 1409-1443.

Childline India Foundation. "Child Protection and Child Rights." 2013.

Chin, Aimee and Praksah, Nishith "The redistributive effects of political reservation for minorities: Evidence from India." Journal of Development Economics, 2011, 96, pp. $265-277$. 
Duflo, Esther. "Why Political Reservations?" Journal of the European Economic Association, April-May 2005, 3 (2-3), pp. 668-678.

Duflo, Esther; Fischer, Greg and Chattopadhyay, Raghabendra. "Efficiency and Rent Seeking in Local Government: Evidence from a Randomized Policy Experiments in India." MIT Working Paper, July 2008.

Edmonds, Eric; Pavcnik, Nina and Topalova, Petia. "Trade Adjustment and Human Capital Investments: Evidence form Indian Tariff Reform." American Economic Journal, 2010, 2(4), pp. $42-75$.

Galanter, Marc. Competing Equalities: Law and the Backward Classes in India. Berkeley: University of California Press, 1984.

Government of India, Ministry of Home Affairs, Office of the Registrar General and Census Commissioner. "Census 2011." 2011.

Government of India, Ministry of Labour \& Employment. "Child Labour Acts, Rules and Schedule." 2013.

Government of India, Planning Commission. "Press Note on Poverty Estimates, 2009-10." 2012.

Krishnan, Nandini. "Political Reservation and Rural Public Good Provision in India." Boston University, 2007.

Mookherjee, Dilip. "Accountability of Local and State Governments in India: An Overview of Recent Research.” Boston University, 2012.

Muralidharan, Karthik. "Public Service in India: Challenges and Opportunities." University of Pennsylvania, Center for the Advanced Study of India, September 2007. 
Ozler, Berk; Datt, Gaurav and Ravallion, Martin. A Database on Poverty and Growth in India, World Bank Development Research Group, Washington DC, 1996.

Pande, Rohini. "Can Mandated Political Representation Increase Policy Influence for Disadvantaged Minorities? Theory and Evidence from India." American Economic Review, September 2003, 93 (4), pp. 1132-1151.

Reserve Bank of India, India's Central Bank. "State Finances: A Study of Budgets 20112002." 2002.

UNICEF. "The Situation of Children in India: A Profile." 2011. 
Table 1

Summary Statistics on the Identification Strategy

\begin{tabular}{|c|c|c|c|c|c|c|c|c|c|c|}
\hline \multirow[b]{2}{*}{ State } & \multicolumn{2}{|c|}{$\begin{array}{l}\text { Reservation Based on } 42^{\text {nd }} \\
\text { Amendment }\end{array}$} & \multicolumn{2}{|c|}{1981 Census } & \multirow[b]{2}{*}{$\begin{array}{l}\text { ST } \\
\text { Census } \\
\text { Pop } \\
\end{array}$} & \multirow[b]{2}{*}{$\begin{array}{l}\text { ST } \\
\text { Current } \\
\text { Pop }\end{array}$} & \multicolumn{4}{|c|}{1991 Census } \\
\hline & $\begin{array}{l}\text { SC } \\
\text { Reservation } \\
\text { Share }\end{array}$ & $\begin{array}{l}\text { ST } \\
\text { Reservation } \\
\text { Share }\end{array}$ & $\begin{array}{l}\text { SC } \\
\text { Census } \\
\text { Pop }\end{array}$ & $\begin{array}{l}\text { SC } \\
\text { Current } \\
\text { Pop }\end{array}$ & & & $\begin{array}{l}\text { SC } \\
\text { Census } \\
\text { Pop }\end{array}$ & $\begin{array}{l}\text { SC } \\
\text { Current } \\
\text { Pop }\end{array}$ & $\begin{array}{l}\text { ST } \\
\text { Census } \\
\text { Pop }\end{array}$ & $\begin{array}{l}\text { ST } \\
\text { Current } \\
\text { Pop }\end{array}$ \\
\hline Andhra Pradesh & 13.27 & 5.10 & 14.87 & 14.97 & 5.93 & 5.97 & 15.93 & 16.14 & 6.31 & 6.54 \\
\hline Assam & 6.35 & 12.70 & & & & & 7.40 & 6.96 & 12.82 & 12.49 \\
\hline Bihar & 14.81 & 8.64 & 14.51 & 14.51 & 8.31 & 8.24 & 14.55 & 14.73 & 7.66 & 7.24 \\
\hline Gujarat & 7.14 & 14.29 & 7.15 & 7.18 & 14.22 & 14.29 & 7.41 & 7.15 & 14.92 & 14.79 \\
\hline Haryana & 18.89 & 0.00 & 19.07 & 19.13 & 0.00 & 0.00 & 19.75 & 19.43 & 0.00 & 0.00 \\
\hline Karnataka & 14.73 & 0.89 & 15.07 & 15.19 & 4.91 & 4.85 & 16.38 & 16.24 & 4.26 & 6.01 \\
\hline Kerala & 9.29 & 0.71 & 10.02 & 10.01 & 1.03 & 1.03 & 9.92 & 9.83 & 1.10 & 1.14 \\
\hline Madhya Pradesh & 13.75 & 23.44 & 14.10 & 14.15 & 22.97 & 23.00 & 14.55 & 14.31 & 23.27 & 23.23 \\
\hline Maharashtra & 6.25 & 7.64 & 7.14 & 7.46 & 9.19 & 9.20 & 11.09 & 10.37 & 9.27 & 8.94 \\
\hline Orissa & 14.97 & 23.13 & 14.66 & 14.81 & 22.43 & 22.41 & 16.20 & 16.46 & 22.21 & 22.15 \\
\hline Punjab & 24.79 & 0.00 & 26.87 & 27.01 & 0.00 & 0.00 & 28.31 & 28.75 & 0.00 & 0.00 \\
\hline Rajasthan & 16.50 & 12.00 & 17.04 & 17.07 & 12.21 & 12.23 & 17.29 & 17.18 & 12.44 & 12.54 \\
\hline Tamil Nadu & 17.95 & 1.28 & 18.35 & 18.43 & 1.07 & 1.07 & 19.18 & 19.04 & 1.03 & 1.04 \\
\hline Uttar Pradesh & 21.65 & 0.24 & 21.16 & 21.14 & 0.21 & 0.21 & 21.05 & 21.00 & 0.21 & 0.21 \\
\hline West Bengal & 20.07 & 5.78 & 21.99 & 22.15 & 5.51 & 5.52 & 23.62 & 23.13 & 5.59 & 5.52 \\
\hline
\end{tabular}

Notes: The actual seats reserved must be an integer. The SC and ST political reservation variable is based on the 1971 census and was later

revised due to 42nd Constitutional Amendment. The SC and ST census population comes from 1981 and 1991 census respectively, while SC and

ST current population is calculated using last preceding census and interpolated linearly as in Pande (2003). 
Table 2

Descriptive Statistics

\begin{tabular}{|c|c|c|}
\hline Variable & Mean & $\begin{array}{l}\text { Standard } \\
\text { deviation }\end{array}$ \\
\hline \multicolumn{3}{|l|}{ Child labor outcomes } \\
\hline Children working & 0.36 & 0.72 \\
\hline Boys working & 0.21 & 0.51 \\
\hline Girls working & 0.15 & 0.15 \\
\hline \multicolumn{3}{|l|}{ Minority political reservation (\%) } \\
\hline SC share reserved & 15.30 & 5.00 \\
\hline ST share reserved & 8.02 & 8.20 \\
\hline \multicolumn{3}{|l|}{ Minority population share controls (\%) } \\
\hline SC census population share & 16.11 & 4.98 \\
\hline ST census population share & 8.39 & 7.90 \\
\hline SC current population share & 16.07 & 6.03 \\
\hline ST current population share & 8.45 & 7.85 \\
\hline \multicolumn{3}{|l|}{ Demographic Controls } \\
\hline SC caste dummy & 0.13 & 0.33 \\
\hline ST caste dummy & 0.07 & 0.25 \\
\hline High caste dummy & 0.26 & 0.44 \\
\hline Brahmin caste dummy & 0.08 & 0.26 \\
\hline OBC dummy & 0.33 & 0.47 \\
\hline Hindu dummy & 0.88 & 0.32 \\
\hline Muslim dummy & 0.07 & 0.26 \\
\hline \multicolumn{3}{|l|}{ Household level controls } \\
\hline Household expenditures & 9.63 & 0.92 \\
\hline Family size & 7.14 & 3.41 \\
\hline HH head education & 2.58 & 1.72 \\
\hline HH head employment status & 0.99 & 0.06 \\
\hline \multicolumn{3}{|l|}{ Other controls } \\
\hline Log of state income per capita last year & 7.19 & 0.39 \\
\hline Election year dummy & 0.17 & 0.38 \\
\hline Rural population share (\%) & 74.89 & 7.61 \\
\hline \multicolumn{3}{|l|}{ Expenditure Controls } \\
\hline Log of total state expenditure per capita & 6.65 & 1.39 \\
\hline Education expenditure share & 21.40 & 3.46 \\
\hline Social security and welfare expenditure share & 1.47 & 0.69 \\
\hline Observations & 8042 & \\
\hline
\end{tabular}


Table 3

Effect of minority political reservation on child labor

\begin{tabular}{|c|c|c|c|c|}
\hline & \multicolumn{4}{|c|}{ Total Children Working } \\
\hline & $(1)$ & $(2)$ & $(3)$ & $(4)$ \\
\hline \multirow[t]{2}{*}{ SC share reserved } & $0.042^{*}$ & $0.037^{*}$ & 0.065 & 0.014 \\
\hline & $(0.020)$ & $(0.018)$ & $(0.038)$ & $(0.026)$ \\
\hline \multirow[t]{2}{*}{ ST share reserved } & $-0.114^{* * *}$ & $-0.108^{* * *}$ & $-0.108^{* * *}$ & $-0.097^{* * *}$ \\
\hline & $(0.032)$ & $(0.031)$ & $(0.029)$ & $(0.029)$ \\
\hline \multirow[t]{2}{*}{ SC census pop share } & -0.15 & -0.135 & -0.157 & -0.104 \\
\hline & $(0.115)$ & $(0.105)$ & $(0.108)$ & $(0.190)$ \\
\hline \multirow[t]{2}{*}{ ST census pop share } & 0.126 & 0.135 & $0.180^{*}$ & $0.202^{* *}$ \\
\hline & $(0.082)$ & $(0.078)$ & $(0.102)$ & $(0.079)$ \\
\hline \multirow[t]{2}{*}{ SC current pop share } & 0.113 & 0.103 & 0.099 & 0.09 \\
\hline & $(0.118)$ & $(0.110)$ & $(0.119)$ & $(0.187)$ \\
\hline \multirow[t]{2}{*}{ ST current pop share } & -0.014 & -0.029 & -0.07 & $-0.109 *$ \\
\hline & $(0.053)$ & $(0.050)$ & $(0.079)$ & $(0.060)$ \\
\hline \multirow[t]{2}{*}{ SC caste dummy } & -0.049 & -0.066 & -0.071 & $-0.089 *$ \\
\hline & $(0.046)$ & $(0.043)$ & $(0.047)$ & $(0.048)$ \\
\hline \multirow[t]{2}{*}{ ST caste dummy } & $0.147^{* *}$ & $0.118^{*}$ & $0.121^{*}$ & 0.084 \\
\hline & $(0.063)$ & $(0.063)$ & $(0.063)$ & $(0.061)$ \\
\hline \multirow[t]{2}{*}{ High caste dummy } & -0.036 & -0.038 & -0.046 & -0.065 \\
\hline & $(0.045)$ & $(0.044)$ & $(0.045)$ & $(0.045)$ \\
\hline \multirow[t]{2}{*}{ Brahmin caste dummy } & $-0.143^{* * *}$ & $-0.121^{* * *}$ & $-0.121 * * *$ & $-0.132^{* * *}$ \\
\hline & $(0.038)$ & $(0.038)$ & $(0.037)$ & $(0.035)$ \\
\hline \multirow[t]{2}{*}{ OBC caste dummy } & -0.025 & -0.028 & -0.029 & -0.047 \\
\hline & $(0.045)$ & $(0.046)$ & $(0.046)$ & $(0.045)$ \\
\hline \multirow[t]{2}{*}{ Hindu dummy } & $0.148^{*}$ & $0.135^{*}$ & $0.124^{*}$ & 0.079 \\
\hline & $(0.069)$ & $(0.068)$ & $(0.063)$ & $(0.076)$ \\
\hline \multirow[t]{2}{*}{ Muslim dummy } & $0.276^{* *}$ & $0.240^{*}$ & $0.228^{*}$ & 0.152 \\
\hline & $(0.128)$ & $(0.121)$ & $(0.107)$ & $(0.102)$ \\
\hline \multirow[t]{2}{*}{ Household expenditures } & & 0.035 & 0.028 & -0.005 \\
\hline & & -0.036 & -0.025 & -0.023 \\
\hline \multirow[t]{2}{*}{ Family size } & & $0.013^{* * *}$ & $0.014^{* * *}$ & $0.017^{* * *}$ \\
\hline & & $(0.003)$ & $(0.004)$ & $(0.005)$ \\
\hline \multirow[t]{2}{*}{ HH head education } & & $-0.046^{* * *}$ & $-0.045^{* * *}$ & $-0.043^{* * *}$ \\
\hline & & $(0.009)$ & $(0.008)$ & $(0.008)$ \\
\hline \multirow[t]{2}{*}{ HH head employment } & & 0.064 & 0.064 & 0.067 \\
\hline & & $(0.136)$ & $(0.136)$ & $(0.130)$ \\
\hline \multirow[t]{2}{*}{ State income last year } & & & 0.059 & $-0.530 * *$ \\
\hline & & & $(0.182)$ & $(0.205)$ \\
\hline \multirow[t]{2}{*}{ Election year dummy } & & & 0.073 & $0.178^{*}$ \\
\hline & & & $(0.101)$ & $(0.098)$ \\
\hline Rural population share & & & -0.003 & -0.003 \\
\hline & & & $(0.005)$ & $(0.005)$ \\
\hline Total state expenditure & & & & $0.528^{*}$ \\
\hline & & & & $(0.258)$ \\
\hline Education expenditure share & & & & -0.02 \\
\hline & & & & $(0.012)$ \\
\hline SS and welfare expend share & & & & $0.112^{* * *}$ \\
\hline & & & & $(0.030)$ \\
\hline Constant & 0.049 & -0.296 & -0.393 & 0.515 \\
\hline & $(0.093)$ & $(0.465)$ & $(1.724)$ & $(1.462)$ \\
\hline Region and year fixed effects & YES & YES & YES & YES \\
\hline Number of observations & 8045 & 8042 & 8042 & 8042 \\
\hline R-squared & 0.06 & 0.07 & 0.07 & 0.08 \\
\hline
\end{tabular}

Notes: Standard errors clustered by state are in parentheses.

Asterisks denote significance: * significant at 10\%; ${ }^{* *}$ significant at $5 \%$; ${ }^{* * *}$ significant at $1 \%$ 
Table 4

Effect of minority political reservation on child labor in disadvantaged groups

\begin{tabular}{|c|c|c|c|c|}
\hline & \multicolumn{4}{|c|}{ Total Children Working } \\
\hline & (1) & $(2)$ & (3) & $(4)$ \\
\hline \multirow[t]{2}{*}{ SC share reserved } & $0.057^{* * *}$ & $0.046^{* * *}$ & 0.049 & 0.027 \\
\hline & $(0.013)$ & $(0.013)$ & $(0.037)$ & $(0.033)$ \\
\hline \multirow[t]{2}{*}{ ST share reserved } & $-0.123^{* * *}$ & $-0.112^{* * *}$ & $-0.105^{* * *}$ & $-0.103^{* * *}$ \\
\hline & $(0.021)$ & $(0.022)$ & $(0.021)$ & $(0.022)$ \\
\hline \multirow[t]{2}{*}{ SC census pop share } & -0.068 & -0.055 & -0.091 & -0.087 \\
\hline & $(0.145)$ & $(0.133)$ & $(0.140)$ & $(0.164)$ \\
\hline \multirow[t]{2}{*}{ ST census pop share } & $0.175^{* *}$ & $0.175^{* *}$ & $0.169^{*}$ & $0.195^{* *}$ \\
\hline & $(0.063)$ & $(0.061)$ & $(0.087)$ & $(0.069)$ \\
\hline \multirow[t]{2}{*}{ SC current pop share } & 0.018 & 0.012 & 0.046 & 0.058 \\
\hline & $(0.152)$ & $(0.140)$ & $(0.144)$ & $(0.171)$ \\
\hline \multirow[t]{2}{*}{ ST current pop share } & -0.050 & -0.061 & -0.059 & -0.090 \\
\hline & $(0.043)$ & $(0.041)$ & $(0.070)$ & $(0.058)$ \\
\hline Demographic controls & YES & YES & YES & YES \\
\hline Household level controls & NO & YES & YES & YES \\
\hline Other controls & NO & NO & YES & YES \\
\hline Expenditure controls & NO & NO & NO & YES \\
\hline Region and year fixed effects & YES & YES & YES & YES \\
\hline Number of observations & 4232 & 4231 & 4231 & 4231 \\
\hline R-squared & 0.06 & 0.07 & 0.07 & 0.08 \\
\hline
\end{tabular}

Notes: Standard errors clustered by state are in parentheses. Demographic controls include caste and religion dummies. Household level controls include log of household expenditures, total family size, and the household head's education and employment status. Other controls include log of state income per capita last year, election dummy, and rural population share. Expenditure controls include the log of total state expenditure per capita, education expenditure revenue share, and social security and welfare expenditure share. Disadvantaged groups are defined as SC, ST, and OBC households.

Asterisks denote significance: * significant at 10\%; ** significant at 5\%; ${ }^{* *}$ significant at $1 \%$ 
Table 5

Effect of minority political reservation on child labor

\begin{tabular}{|c|c|c|c|c|c|c|c|c|}
\hline & \multicolumn{4}{|c|}{ Total Boys Working } & \multicolumn{4}{|c|}{ Total Girls Working } \\
\hline & (1) & $(2)$ & (3) & $(4)$ & (5) & $(6)$ & (7) & $(8)$ \\
\hline \multirow[t]{2}{*}{ SC share reserved } & $0.021^{*}$ & $0.019^{*}$ & 0.030 & -0.006 & $0.021^{*}$ & $0.018^{*}$ & $0.035^{* *}$ & 0.019 \\
\hline & $(0.011)$ & $(0.010)$ & $(0.022)$ & $(0.014)$ & $(0.010)$ & $(0.009)$ & $(0.016)$ & $(0.013)$ \\
\hline \multirow[t]{2}{*}{ ST share reserved } & $-0.062^{* * *}$ & $-0.059^{* * *}$ & $-0.059^{* * *}$ & $-0.049^{* * *}$ & $-0.052^{* * *}$ & $-0.049^{* * *}$ & $-0.049^{* * *}$ & $-0.049^{* * *}$ \\
\hline & $(0.016)$ & $(0.016)$ & $(0.015)$ & $(0.015)$ & $(0.016)$ & $(0.015)$ & $(0.014)$ & $(0.014)$ \\
\hline \multirow[t]{2}{*}{ SC census pop share } & $-0.124^{*}$ & $-0.118^{* *}$ & $-0.127^{* *}$ & -0.070 & -0.026 & -0.017 & -0.030 & -0.034 \\
\hline & $(0.059)$ & $(0.054)$ & $(0.055)$ & $(0.106)$ & $(0.057)$ & $(0.051)$ & $(0.054)$ & $(0.086)$ \\
\hline \multirow[t]{2}{*}{ ST census pop share } & 0.064 & 0.069 & 0.090 & $0.098^{* *}$ & 0.062 & 0.065 & $0.090^{*}$ & $0.104^{* *}$ \\
\hline & $(0.041)$ & $(0.041)$ & $(0.057)$ & $(0.043)$ & $(0.041)$ & $(0.038)$ & $(0.046)$ & $(0.037)$ \\
\hline \multirow[t]{2}{*}{ SC current pop share } & $0.108^{*}$ & $0.104^{*}$ & 0.103 & 0.076 & 0.006 & -0.001 & -0.004 & 0.014 \\
\hline & $(0.059)$ & $(0.056)$ & $(0.061)$ & $(0.104)$ & $(0.059)$ & $(0.055)$ & $(0.060)$ & $(0.086)$ \\
\hline \multirow[t]{2}{*}{ ST current pop share } & -0.004 & -0.013 & -0.032 & -0.055 & -0.010 & -0.016 & -0.038 & $-0.055^{*}$ \\
\hline & $(0.027)$ & $(0.026)$ & $(0.045)$ & $(0.032)$ & $(0.026)$ & $(0.024)$ & $(0.035)$ & $(0.028)$ \\
\hline Demographic controls & YES & YES & YES & YES & YES & YES & YES & YES \\
\hline Household level controls & NO & YES & YES & YES & NO & YES & YES & YES \\
\hline Other controls & NO & NO & YES & YES & NO & NO & YES & YES \\
\hline \multirow{2}{*}{$\begin{array}{l}\text { Expenditure controls } \\
\text { Region and year fixed } \\
\text { effects }\end{array}$} & NO & NO & NO & YES & NO & NO & NO & YES \\
\hline & YES & YES & YES & YES & YES & YES & YES & YES \\
\hline Number of observations & 8045 & 8042 & 8042 & 8042 & 8045 & 8042 & 8042 & 8042 \\
\hline R-squared & 0.04 & 0.06 & 0.06 & 0.07 & 0.03 & 0.04 & 0.04 & 0.04 \\
\hline
\end{tabular}

Notes: Standard errors clustered by state are in parentheses. Demographic controls include caste and religion dummies. Household level controls include log of household expenditures, total family size, and the household head's education and employment status. Other controls include log of state income per capita last year, election dummy, and rural population share. Expenditure controls include the log of total state expenditure per capita, education expenditure revenue share, and social security and welfare expenditure share.

Asterisks denote significance: * significant at 10\%; ** significant at 5\%; *** significant at $1 \%$ 
Table 6

Effect of minority political reservation on child labor in disadvantaged households

\begin{tabular}{|c|c|c|c|c|c|c|c|c|}
\hline & \multicolumn{4}{|c|}{ Total Boys Working } & \multicolumn{4}{|c|}{ Total Girls Working } \\
\hline & $(1)$ & $(2)$ & $(3)$ & $(4)$ & (5) & $(6)$ & (7) & $(8)$ \\
\hline \multirow[t]{2}{*}{ SC share reserved } & $0.027^{* * *}$ & $0.021^{* *}$ & 0.020 & -0.003 & $0.030^{* * *}$ & $0.025^{* * *}$ & 0.030 & $0.030^{*}$ \\
\hline & $(0.008)$ & $(0.007)$ & $(0.021)$ & $(0.019)$ & $(0.008)$ & $(0.008)$ & $(0.018)$ & $(0.015)$ \\
\hline \multirow[t]{2}{*}{ ST share reserved } & $-0.063^{* * *}$ & $-0.057^{* * *}$ & $-0.053^{* * *}$ & $-0.048^{* * *}$ & $-0.059 * * *$ & $-0.055^{* * *}$ & $-0.052^{* * *}$ & $-0.055^{* * *}$ \\
\hline & $(0.010)$ & $(0.010)$ & $(0.010)$ & $(0.010)$ & $(0.012)$ & $(0.012)$ & $(0.011)$ & $(0.013)$ \\
\hline \multirow[t]{2}{*}{ SC census pop share } & -0.058 & -0.051 & -0.069 & -0.044 & -0.010 & -0.003 & -0.023 & -0.043 \\
\hline & $(0.079)$ & $(0.072)$ & $(0.076)$ & $(0.080)$ & $(0.072)$ & $(0.067)$ & $(0.073)$ & $(0.089)$ \\
\hline \multirow[t]{2}{*}{ ST census pop share } & $0.089 * * *$ & $0.088^{* *}$ & $0.086^{*}$ & $0.106^{* *}$ & $0.086^{* *}$ & $0.087^{* *}$ & $0.082^{*}$ & $0.089 * *$ \\
\hline & $(0.030)$ & $(0.030)$ & $(0.047)$ & $(0.037)$ & $(0.034)$ & $(0.032)$ & $(0.042)$ & $(0.035)$ \\
\hline \multirow[t]{2}{*}{ SC current pop share } & 0.038 & 0.035 & 0.054 & 0.046 & -0.020 & -0.023 & -0.008 & 0.012 \\
\hline & $(0.082)$ & $(0.075)$ & $(0.073)$ & $(0.081)$ & $(0.077)$ & $(0.073)$ & $(0.078)$ & $(0.094)$ \\
\hline \multirow[t]{2}{*}{ ST current pop share } & -0.026 & -0.031 & -0.032 & $-0.060^{*}$ & -0.024 & -0.029 & -0.027 & -0.030 \\
\hline & $(0.021)$ & $(0.021)$ & $(0.040)$ & $(0.031)$ & $(0.023)$ & $(0.020)$ & $(0.032)$ & $(0.030)$ \\
\hline Demographic controls & YES & YES & YES & YES & YES & YES & YES & YES \\
\hline Household level controls & NO & YES & YES & YES & NO & YES & YES & YES \\
\hline Other controls & NO & NO & YES & YES & NO & NO & YES & YES \\
\hline \multirow{2}{*}{$\begin{array}{l}\text { Expenditure controls } \\
\text { Region and year fixed } \\
\text { effects }\end{array}$} & NO & NO & NO & YES & NO & NO & NO & YES \\
\hline & YES & YES & YES & YES & YES & YES & YES & YES \\
\hline Number of observations & 4232 & 4231 & 4231 & 4231 & 4232 & 4231 & 4231 & 4231 \\
\hline R-squared & 0.04 & 0.05 & 0.05 & 0.05 & 0.03 & 0.04 & 0.04 & 0.04 \\
\hline
\end{tabular}

Notes: Standard errors clustered by state are in parentheses. Demographic controls include caste and religion dummies. Household level controls include household expenditures, total family size, and the household head's education and employment status. Other controls include log of state income per capita last year, election dummy, and rural population share. Expenditure controls include the log of total state expenditure per capita, education expenditure revenue share, and social security and welfare expenditure share. Disadvantaged groups are defined as SC ST and OBC households.

Asterisks denote significance: * significant at 10\%; ${ }^{* *}$ significant at $5 \%$; ${ }^{* *}$ significant at $1 \%$ 
Table 7

Robustness checks
(1)
(2)
(3)
(4)

Panel A: Total Children Working

SC share reserved

$\begin{array}{llll}0.014 & -0.001 & 0.014 & 0.014 \\ (0.026) & (0.026) & (0.017) & (0.015) \\ -0.097^{* * *} & -0.080^{* *} & -0.066^{* * *} & -0.097^{* * *} \\ (0.029) & (0.029) & (0.016) & (0.013)\end{array}$

Panel B: Total Boys Working

$\mathrm{SC}$ share reserved

$\begin{array}{llll}-0.006 & -0.011 & -0.004 & -0.006 \\ (0.014) & (0.014) & (0.012) & (0.010) \\ -0.049^{* * *} & -0.037^{* *} & -0.039^{* * *} & -0.049^{* * *} \\ (0.015) & (0.014) & (0.012) & (0.009)\end{array}$

Panel C: Total Girls Working

\begin{tabular}{lllll} 
SC share reserved & 0.019 & 0.01 & $0.019^{*}$ & $0.019^{* *}$ \\
ST share reserved & $(0.013)$ & $(0.013)$ & $(0.010)$ & $(0.009)$ \\
& $-0.049^{* * *}$ & $-0.043^{* *}$ & $-0.040^{* * *}$ & $-0.049^{* * *}$ \\
& $(0.014)$ & $(0.015)$ & $(0.010)$ & $(0.008)$ \\
\hline
\end{tabular}

Notes: Standard errors clustered by state are in parentheses. Results displayed in each column come from a separate regression that also controls for region and time fixed effects, SC and ST population shares in the last preceding census, SC and ST current population shares, caste and religion dummies, log of household expenditures, total family size, household head's education and employment status, log of state income per capita last year, election dummy, rural population share, log of total state expenditure per capita, education expenditure revenue share, and social security and welfare expenditure share. The regressions in each column have the following additional features: In Column 1, Panel A shows the estimates originally reported in Column 4 of Table 2, while Panel B and C show the estimates originally reported in Columns 4 and 8 of Table 4 . Column 2 includes the number of girls age $0-4$, boys age $0-4$, girls age $5-9$, boys age $5-9$, girls age $10-14$, and boys age 10-14 in the household as controls. Column 3, Panel A replaces the dependent variable with a binary variable equal to one if the household has a child working, zero otherwise. Panels B and C replace the dependent variables with a binary variable equal to one if the household has a boy or girl working respectively. Column 4 includes state random effects. Asterisks denote significance: * significant at $10 \%$; $^{* *}$ significant at $5 \%$; ${ }^{* * *}$ significant at $1 \%$ 
Table 8

Heterogeneity in effect on child labor in all households

\begin{tabular}{|c|c|c|c|c|c|}
\hline & Base & Isolation & $\begin{array}{l}\text { Social } \\
\text { heterogeneity }\end{array}$ & Congress support & $\begin{array}{l}\text { 73rd } \\
\text { Amendment }\end{array}$ \\
\hline Variable 1 & & SC isolation \% & Caste frag. $\%$ & SC Congress majority & After 1993 \\
\hline Variable 2 & (1) & $\begin{array}{l}\text { ST isolation \% } \\
\text { (2) }\end{array}$ & $\begin{array}{l}\text { Caste frag. \% } \\
\text { (3) }\end{array}$ & $\begin{array}{l}\text { ST Congress majority } \\
\text { (4) }\end{array}$ & $\begin{array}{l}\text { After } 1993 \\
\text { (5) }\end{array}$ \\
\hline SC share reserved & $\begin{array}{l}0.014 \\
(0.026)\end{array}$ & $\begin{array}{l}-0.166^{* * *} \\
(0.046)\end{array}$ & $\begin{array}{l}-0.034 \\
(0.033)\end{array}$ & $\begin{array}{l}0.100^{*} \\
(0.050)\end{array}$ & $\begin{array}{l}-0.024 \\
(0.026)\end{array}$ \\
\hline ST share reserved & $\begin{array}{l}-0.097^{* * *} \\
(0.029)\end{array}$ & $\begin{array}{l}-0.114^{* * *} \\
(0.015)\end{array}$ & $\begin{array}{l}-0.088^{* *} \\
(0.029)\end{array}$ & $\begin{array}{l}-0.114^{* * *} \\
(0.030)\end{array}$ & $\begin{array}{l}-0.070^{* *} \\
(0.028)\end{array}$ \\
\hline SC share reserved $\mathrm{x}$ variable 1 & & $\begin{array}{l}-0.008^{* * *} \\
(0.002)\end{array}$ & $\begin{array}{l}-0.005^{* *} \\
(0.002)\end{array}$ & $\begin{array}{l}-0.026 \\
(0.023)\end{array}$ & $\begin{array}{l}0.020^{* *} \\
(0.009)\end{array}$ \\
\hline ST share reserved $x$ variable 2 & & $\begin{array}{l}0.006^{* * *} \\
(0.001)\end{array}$ & $\begin{array}{l}0.001 \\
(0.002)\end{array}$ & $\begin{array}{l}-0.015^{* * *} \\
(0.004)\end{array}$ & $\begin{array}{l}0.015^{* *} \\
(0.006)\end{array}$ \\
\hline Mean (s.d.) for variable 1 & & $\begin{array}{l}2.071 \\
(1.819)\end{array}$ & $\begin{array}{l}93.024 \\
(3.552)\end{array}$ & $\begin{array}{l}0.388 \\
(0.487)\end{array}$ & $\begin{array}{l}0.606 \\
(0.489)\end{array}$ \\
\hline Mean (s.d.) for variable 2 & & $\begin{array}{l}12.569 \\
(10.659)\end{array}$ & $\begin{array}{l}93.024 \\
(3.552)\end{array}$ & $\begin{array}{l}0.24 \\
(0.427)\end{array}$ & $\begin{array}{l}0.606 \\
(0.489)\end{array}$ \\
\hline
\end{tabular}

Notes: Standard errors clustered by state are in parentheses. Results displayed in each column come from a separate regression that also controls for region and time fixed effects, SC and ST population shares in the last preceding census, and SC and ST current population shares, demographic controls, household level controls, other controls, and expenditure controls. In addition, the specification in Column 4 controls for Congress Party share of SC, ST and all Parliament seats.

Asterisks denote significance: * significant at 10\%; ** significant at 5\%; *** significant at $1 \%$ 
Table 9

Heterogeneity in effect on child labor in all households by gender

\begin{tabular}{|c|c|c|c|c|c|}
\hline \multirow[t]{2}{*}{ Panel A } & \multicolumn{5}{|c|}{ Total Boys Working } \\
\hline & Base & Isolation & $\begin{array}{l}\text { Social } \\
\text { heterogeneity }\end{array}$ & Congress support & $\begin{array}{l}\text { 73rd } \\
\text { Amendment }\end{array}$ \\
\hline Variable 1 & & $\mathrm{SC}$ isolation \% & Caste frag. \% & SC Congress majority & After 1993 \\
\hline \multirow[t]{2}{*}{ Variable 2} & & ST isolation $\%$ & Caste frag. \% & ST Congress majority & After 1993 \\
\hline & (1) & $(2)$ & (3) & $(4)$ & (5) \\
\hline \multirow[t]{2}{*}{ SC share reserved } & -0.006 & $-0.105^{* * *}$ & $-0.036^{*}$ & 0.032 & $-0.025^{*}$ \\
\hline & $(0.014)$ & $(0.026)$ & $(0.017)$ & $(0.028)$ & $(0.013)$ \\
\hline \multirow[t]{2}{*}{ ST share reserved } & $-0.049 * * *$ & $-0.058^{* * *}$ & $-0.039 * *$ & $-0.056^{* * *}$ & $-0.034 * *$ \\
\hline & $(0.015)$ & $(0.008)$ & $(0.015)$ & $(0.016)$ & $(0.707)$ \\
\hline \multirow[t]{2}{*}{ SC share reserved $\mathrm{x}$ variable 1} & & $-0.005^{* * *}$ & $-0.003^{* * *}$ & -0.016 & $0.012^{* *}$ \\
\hline & & $(0.001)$ & $(0.001)$ & $(0.013)$ & $(0.005)$ \\
\hline \multirow[t]{2}{*}{ ST share reserved $x$ variable 2} & & $0.003^{* * *}$ & 0.001 & $-0.007 * *$ & $0.008^{* *}$ \\
\hline & & $(0.001)$ & $(0.001)$ & $(0.003)$ & $(0.004)$ \\
\hline \multirow[t]{2}{*}{ Panel B } & \multicolumn{5}{|c|}{ Total Girls Working } \\
\hline & Base & Isolation & $\begin{array}{l}\text { Social } \\
\text { heterogeneity }\end{array}$ & Congress support & $\begin{array}{l}\text { 73rd } \\
\text { Amendment }\end{array}$ \\
\hline Variable 1 & & SC isolation \% & Caste frag. \% & SC Congress majority & After 1993 \\
\hline \multirow[t]{2}{*}{ Variable 2} & & ST isolation $\%$ & Caste frag. \% & ST Congress majority & After 1993 \\
\hline & (1) & $(2)$ & (3) & (4) & $(5)$ \\
\hline \multirow[t]{2}{*}{ SC share reserved } & 0.019 & $-0.061^{* *}$ & 0.002 & $0.067^{* *}$ & 0.001 \\
\hline & $(0.013)$ & $(0.021)$ & $(0.017)$ & $(0.024)$ & $(0.013)$ \\
\hline \multirow[t]{2}{*}{ ST share reserved } & $-0.049^{* * *}$ & $-0.056^{* * *}$ & $-0.048^{* * *}$ & $-0.058^{* * *}$ & $-0.035^{* *}$ \\
\hline & $(0.014)$ & $(0.008)$ & $(0.015)$ & $(0.014)$ & $(0.014)$ \\
\hline \multirow[t]{2}{*}{ SC share reserved $\mathrm{x}$ variable 1} & & $-0.003^{* *}$ & $-0.002^{* *}$ & -0.01 & $0.008^{*}$ \\
\hline & & $(0.001)$ & $(0.001)$ & $(0.011)$ & $(0.004)$ \\
\hline \multirow[t]{2}{*}{ ST share reserved $\mathrm{x}$ variable 2} & & $0.003^{* * *}$ & 0.000 & $-0.008^{* * *}$ & $0.007^{* * *}$ \\
\hline & & $(0.001)$ & $(0.001)$ & $(0.002)$ & $(0.002)$ \\
\hline \multirow[t]{2}{*}{ Mean (s.d.) for variable 1} & & 2.071 & 93.024 & 0.388 & 0.606 \\
\hline & & $(1.819)$ & $(3.552)$ & $(0.487)$ & $(0.489)$ \\
\hline \multirow[t]{2}{*}{ Mean (s.d.) for variable 2} & & 12.569 & 93.024 & 0.24 & 0.606 \\
\hline & & (10.659) & $(3.552)$ & $(0.427)$ & $(0.489)$ \\
\hline
\end{tabular}

Notes: Standard errors clustered by state are in parentheses. Results displayed in each column come from a separate regression that also controls for region time fixed effects, SC and ST population shares in the last preceding census, and SC and ST current population shares, demographic controls, household level controls, other controls, and expenditure controls. In addition, the specification in Column 4 controls for Congress Party share of SC, ST and all Parliament seats. Asterisks denote significance: * significant at 10\%; ** significant at 5\%; ${ }^{* *}$ significant at $1 \%$ 


\section{APPENDIX A1}

Table 10

Effect of minority political reservation on child labor in SC households

\begin{tabular}{|c|c|c|c|c|}
\hline & \multicolumn{4}{|c|}{ Total Children Working } \\
\hline & (1) & $(2)$ & (3) & $(4)$ \\
\hline \multirow[t]{2}{*}{ SC share reserved } & $0.066^{* * *}$ & $0.063^{* *}$ & $0.097^{* * *}$ & $0.080^{* * *}$ \\
\hline & $(0.018)$ & $(0.021)$ & $(0.026)$ & $(0.025)$ \\
\hline \multirow[t]{2}{*}{ ST share reserved } & $-0.114^{* * *}$ & $-0.119^{* * *}$ & $-0.111^{* * *}$ & $-0.109 * * *$ \\
\hline & $(0.018)$ & $(0.016)$ & $(0.014)$ & $(0.015)$ \\
\hline \multirow[t]{2}{*}{ SC census pop share } & $-0.152^{* *}$ & $-0.134^{*}$ & $-0.211^{* *}$ & $-0.214^{* *}$ \\
\hline & $(0.068)$ & $(0.069)$ & $(0.076)$ & $(0.096)$ \\
\hline \multirow[t]{2}{*}{ ST census pop share } & $0.111^{*}$ & $0.136^{* *}$ & $0.205^{* * *}$ & $0.211^{* * *}$ \\
\hline & $(0.056)$ & $(0.048)$ & $(0.065)$ & $(0.060)$ \\
\hline \multirow[t]{2}{*}{ SC current pop share } & 0.095 & 0.079 & 0.127 & 0.143 \\
\hline & $(0.075)$ & $(0.076)$ & $(0.077)$ & $(0.091)$ \\
\hline \multirow[t]{2}{*}{ ST current pop share } & 0.003 & -0.017 & -0.087 & $-0.096^{*}$ \\
\hline & $(0.042)$ & $(0.037)$ & $(0.053)$ & $(0.049)$ \\
\hline Demographic controls & YES & YES & YES & YES \\
\hline Household level controls & NO & YES & YES & YES \\
\hline Other controls & NO & NO & YES & YES \\
\hline Expenditure controls & NO & NO & NO & YES \\
\hline Region and year fixed effects & YES & YES & YES & YES \\
\hline Number of observations & 1033 & 1033 & 1033 & 1033 \\
\hline R-squared & 0.04 & 0.07 & 0.07 & 0.08 \\
\hline
\end{tabular}

Notes: Standard errors clustered by state are in parentheses. Demographic controls include caste and religion dummies. Household level controls include log of household expenditures, total family size, and the household head's education and employment status. Other controls include log of state income per capita last year, election dummy, and rural population share. Expenditure controls include the log of total state expenditure per capita, education expenditure revenue share, and social security and welfare expenditure share. Disadvantaged groups are defined as SC, ST, and OBC households.

Asterisks denote significance: * significant at 10\%; ** significant at $5 \%$; *** significant at $1 \%$ 
Table 11

Effect of minority political reservation on child labor in ST households

\begin{tabular}{|c|c|c|c|c|}
\hline & \multicolumn{4}{|c|}{ Total Children Working } \\
\hline & (1) & $(2)$ & $(3)$ & $(4)$ \\
\hline \multirow[t]{2}{*}{ SC share reserved } & 0.027 & 0.006 & 0.108 & 0.053 \\
\hline & $(0.052)$ & $(0.047)$ & $(0.065)$ & $(0.077)$ \\
\hline \multirow[t]{2}{*}{ ST share reserved } & -0.007 & 0.006 & 0.040 & 0.055 \\
\hline & $(0.132)$ & $(0.126)$ & $(0.141)$ & $(0.146)$ \\
\hline \multirow[t]{2}{*}{ SC census pop share } & -0.188 & -0.136 & -0.202 & 0.096 \\
\hline & $(0.478)$ & $(0.443)$ & $(0.337)$ & $(0.476)$ \\
\hline \multirow[t]{2}{*}{ ST census pop share } & 0.146 & 0.129 & 0.228 & 0.295 \\
\hline & $(0.226)$ & $(0.210)$ & $(0.283)$ & $(0.206)$ \\
\hline \multirow[t]{2}{*}{ SC current pop share } & 0.126 & 0.091 & 0.068 & -0.194 \\
\hline & $(0.515)$ & $(0.477)$ & $(0.374)$ & $(0.480)$ \\
\hline \multirow[t]{2}{*}{ ST current pop share } & -0.140 & -0.138 & -0.256 & $-0.350^{* *}$ \\
\hline & $(0.126)$ & $(0.118)$ & $(0.179)$ & $(0.144)$ \\
\hline Demographic controls & YES & YES & YES & YES \\
\hline Household level controls & NO & YES & YES & YES \\
\hline Other controls & NO & NO & YES & YES \\
\hline Expenditure controls & NO & NO & NO & YES \\
\hline Region and year fixed effects & YES & YES & YES & YES \\
\hline Number of observations & 544 & 544 & 544 & 544 \\
\hline R-squared & 0.06 & 0.07 & 0.08 & 0.08 \\
\hline
\end{tabular}

Notes: Standard errors clustered by state are in parentheses. Demographic controls include caste and religion dummies. Household level controls include log of household expenditures, total family size, and the household head's education and employment status. Other controls include log of state income per capita last year, election dummy, and rural population share. Expenditure controls include the log of total state expenditure per capita, education expenditure revenue share, and social security and welfare expenditure share. Disadvantaged groups are defined as SC, ST, and OBC households.

Asterisks denote significance: * significant at 10\%; ${ }^{* *}$ significant at 5\%; ${ }^{* *}$ significant at $1 \%$ 